\title{
TRADISI RIHLAH ‘ILMIYYAH DI KALANGAN ULAMA HADIS
}

\section{Dzikri Nirwana}

Jurusan Tafsir Hadis Fakultas Ushuluddin dan Humaniora

IAIN Antasari Banjarmasin

Diterima tanggal 5 Pebruari 2015 / Disetujui tanggal 19 Meret 2015

\begin{abstract}
The tradition of hijrah seek knowledge often referred to as the 'ilmiyyah riblah travel or study that has been inherited by those earlier (the salaf al-shalih) to the current generation. This paper specifically highlights the riblah ilmiyyah tradition among the scholars of Hadith in historical perspective. The presence technological advances and information now that it's been more advanced, as well as easily accessible online anytime and any where, does not mean riblah 'ilmiyyah by the time this becomes less relevant again. However, because a meeting directly with the teachers remain necessary in order to keep the scientific ethics and objectivity of scholarship which in turn will generate sustainable goodness value, or in the language of religion is referred to as the " blessing 'of science. This was the movitasi scholars of classical tradition to keep doing this to perlawatan seeking other areas, despite having to go through the difficulties and obstacles
\end{abstract}

Kata kunci: riblah 'ilmiyyah, perspektif kesejarahan, berkah 'ilmu.

\section{Pendahuluan}

Dalam Islam, belajar atau menuntut ilmu merupakan hal yang sangat ditekankan. Ketinggian derajat seseorang di sisi Allah SW'T. tergantung pada iman dan ilmu yang dimilikinya. Oleh karena itu, baik dalam al-Qur'an maupun hadis nabi, para penuntut ilmu memiliki kedudukan yang mulia, ${ }^{1}$ bahkan mereka setara dengan para pejuang di jalan Allah. ${ }^{2}$ Dari sini, belajar merupakan kata kunci dalam setiap usaha pendidikan, untuk menempa diri menjadi makhluk terbaik (ahsanu taqwîm) dari makhluk-makhluk Allah lainnya.

Mengingat usaha pendidikan ini berlangsung seumur hidup, maka sebenarnya tidak ada istilah 'tamat' dalam belajar. Inilah yang sering disebut dengan pendidikan seumur hidup [long

${ }^{1}$ Lihat Q.S. al-Mujâdalah/58:11 sebagai berikut;

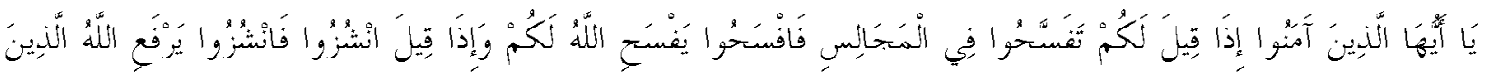

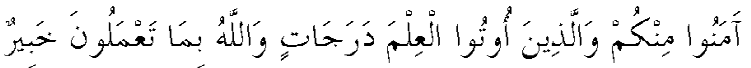

${ }^{2}$ Lihat misalnya hadis riwayat Imam al-Tirmidzî (w. 279 H.) dari Anas ibn Mâlik kitab al-ílm bab fadbl thalab al-ilm, dengan redaksi riwayat sebagai berikut:

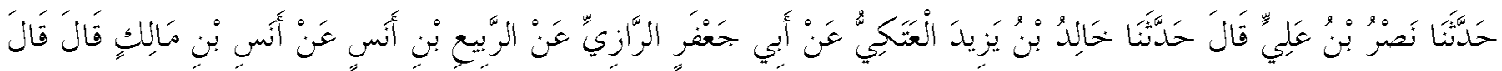

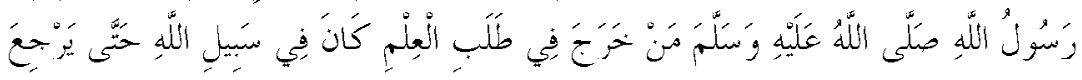

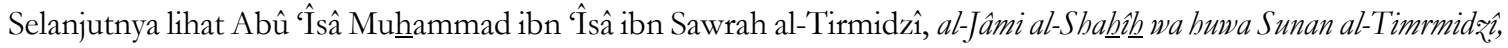

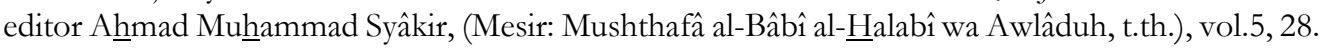


live education), atau pendidikan dari buaian hingga liang lahat [minal mabdi ilal labdi]. Meskipun demikian, secara formal pendidikan memiliki batasan dan jenjang dari tingkat pendidikan pra sekolah, dasar, menengah, atas, hingga perguruan tinggi, yang semuanya memiliki perbedaan dalam sistem pembelajarannya pada setiap jenjang pendidikan. Tentunya tidak setiap wilayah memiliki semua jenjang pendidikan tersebut, terutama di daerah pedalaman, pedesaan, dan wilayah terpencil lainnya yang sangat terbatas lembaga pendidikannya. Berbeda dengan daerah perkotaan yang memiliki fasilitas pendidikan yang relatif banyak dan mencakup semua tingkat pendidikan.

Oleh karena itu, mereka yang akan melanjutkan pendidikannya ke jenjang yang lebih tinggi, sementara di daerahnya tidak ada akses untuk studi lanjutan, atau ingin mendapatkan pendidikan yang lebih baik dan lebih bermutu, biasanya pergi ke wilayah-wilayah lain yang memiliki akses pendidikan yang lebih lengkap, dari antar kota, kapubaten, propinsi, hingga antar negara. Tradisi seperti inilah yang dalam Islam lazim disebut sebagai riblah ilmiyyah atau perjalanan menuntut ilmu yang telah diwariskan oleh orang-orang terdahulu (salaf al-shâlib) hingga generasi sekarang. Tulisan ini secara spesifik menyoroti tradisi riblah 'ilmiyyah di kalangan ulama hadis dalam perspektif kesejarahan.

\section{Pembahasan}

\section{Rihlah 'Ilmiyyah; Telaah Historis-Konseptual}

Secara literal, riblah berasal dari akar kata rabila-yarbilu-riblatan yang berarti melakukan perjalanan (al-irtihâl) dengan menggunakan kendaraan [unta dan lainnya]. ${ }^{3}$ Makna riblah ini dapat dilihat misalnya dalam Q.S.Quraisy/106:2, yaitu îlâfihim riblatasy-syâta’i wash-shayf [(yaitu) kebiasaan mereka (orang-orang Quraisy) bepergian di musim dingin dan musim panas]. Dalam beberapa penafsiran, diungkapkan bahwa riblah yang dimaksud pada ayat ini adalah perjalanan ke luar daerah dengan tujuan berdagang. Tradisi ini menjadi sesuatu yang menjadi kebiasaan bangsa Arab dalam mempertahankan kehidupan ekonomi mereka. ${ }^{4}$ Dalam sejumlah ayat alQur'an, juga diisyaratkan agar manusia melakukan suatu perjalanan, misalnya ungkapan albijrah, ${ }^{5}$ atau al-sirah, ${ }^{6}$ untuk mempertahankan kehidupan mereka.

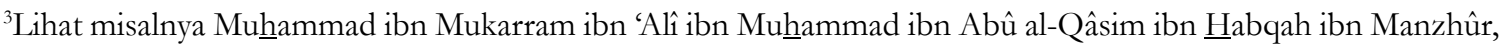
Lisân al-Áaba, (Kairo: Dâr al-Ma'ârif, t.th.), vol.3, no.13, 1608-1611; Abû al-Husayn Aḥmad ibn Fâris ibn Zakariyyâ, Mu’jam Maqâyîs al-Lughah, editor 'Abd al-Salâm Muhammad Hârûn, (Beirut: Dâr al-Fikr, 1979), vol. 2, 497.

${ }^{4}$ Orang-orang Quraisy biasa mengadakan perjalanan, terutama untuk berdagang ke negeri Syam pada musim panas dan ke negeri Yaman pada musim dingin. Dalam perjalanan itu mereka mendapat jaminan keamanan dari penguasa-penguasa dari negeri-negeri yang dilaluinya. Ini adalah nikmat Allah yang begitu besar, maka sewajarnyalah mereka menyembah-Nya. Selanjutnya lihat misalnya Abû al-Fidâ' al-Hâfizh ibn Katsîr al-Dimasyqî, Tafsîr al-Qur'ân al-'Ažhîm, (Beirut: Dâr al-Fikr, 2009), vol.4, 2076; Muhammad 'Alî al-Shâbûnî, Shafwa ah al-Tafâsir, (Beirut: Dâr al-Fikr, 2001), vol.3, 580.

${ }^{5}$ Ungkapan al-hijrah ini dapat dilihat misalnya Q.S. al-Nisa/ 4:97, sebagai berikut;

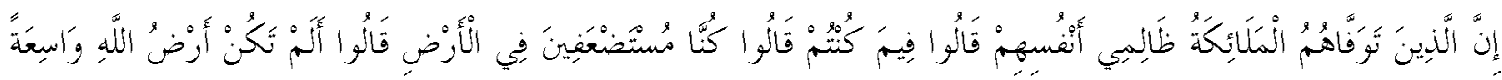

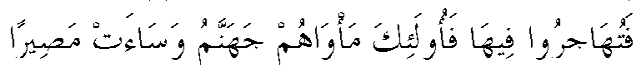

${ }^{6}$ Ungkapan al-sîrah ini dapat dilihat misalnya Q.S. al-Naml/ 27:69, sebagai berikut;

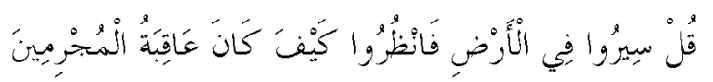


Berpijak pada landasan normatif inilah, maka perintah untuk melakukan perjalanan itu diperbolehkan dengan tujuan agar manusia melihat dan belajar tentang perihal dan keadaan bangsa lain dalam rangka memperoleh pelajaran ataupun untuk menyelamatkan diri dari kebinasaan di tempat tinggal yang lama. Sedangkan ungkapan ilmiyyah merupakan bentuk mashdar shinầ̂ dari akar kata 'alima-ya'lamu-'ilman yang berarti mengetahui. ${ }^{7}$ Dari sini, riblah ilmiyyah dapat diartikan sebagai sebuah perjalanan yang ditempuh keluar wilayah atau daerah tempat tinggalnya dalam rangka kegiatan keilmuan.

Ibn Khaldun (w. 808 H.), mengistilahkannya dengan al-riblah fî̀ thalab al-ílm (perjalanan menuntut ilmu), yang dilakukan untuk bertemu langsung dengan para guru dalam rangka menambah kesempurnaan ilmu. Lebih lanjut dinyatakan bahwa dengan melakukan riblah 'ilmiyyah terlebih lagi langsung bertatap muka dengan guru, hal ini memiliki pengaruh yang sangat besar. Karena akan lebih memperkokoh pemahaman serta merasuk dalam hati, tanpa menegasikan metode-metode lain yang dapat dilakukan dalam menuntut ilmu. Dengan metode ini pula seorang penuntut ilmu dapat memperoleh istilah-istilah baru serta variasi metode pengajaran dari guruguru yang ditemuinya. Gambaran praktik riblah ini dalam pendidikan Islam klasik dipraktekkan secara luas oleh para ilmuwan yang hidup pada masa tersebut. ${ }^{8}$

Di kalangan ahli hadis, riblah ilmiyyah dilakukan dalam upaya pengumpulan hadis-hadis Nabi saw. yang sudah terlanjur menyebar ke berbagai wilayah dunia Islam. Perjalanan ilmiah ini diistilahkan al-Khathîb al-Baghdâdî (w. 463 H.) dalam karyanya yang berjudul al-riblah fî thalab al-badîts (perjalanan mencari hadis), yang merupakan metode atau teknik yang lazim ditempuh oleh para ahli hadis untuk mendapatkan sesuatu [ilmu] yang bersifat ilmiah. ${ }^{9}$ Secara spesifik, alKhumaysî mendefinisikannya sebagai perjalanan ke luar wilayah atau negera untuk bertemu dengan para guru hadis dan mengambil hadis dari mereka dengan metode perawian tertentu. ${ }^{10}$ Perjalanan ilmiah ini bagi para ahli hadis dimaksudkan untuk mendapatkan sanad dan matn hadis yang belum ada di tangan mereka sebelumnya. ${ }^{11}$ Menurut al-Khathîb al-Baghdâdî, bahwa perjalanan mencari hadis memiliki dua maksud; pertama, untuk mendapatkan sanad tertinggi

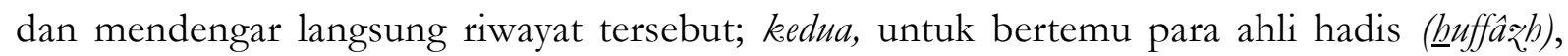
berdikusi dan belajar dari mereka. Apabila dua hal ini sudah ada di wilayahnya dan tidak ada di daerah lain, maka melakukan perjalanan ilmiah tidak lagi diperlukan karena keduanya sudah terpenuhi di wilayah tersebut. ${ }^{12}$

Tradisi riblah ini telah mulai dilakukan di kalangan sahabat, kemudian diteruskan oleh generasi tabi'in, dan demikian seterusnya sampai akhirnya berhasil disusun kitab-kitab hadis

\footnotetext{
${ }^{7}$ Lihat misalnya Ibn Fâris, Mu'jam Maqâyî́s al-Lughah, vol.4, 109-111.

${ }^{8}$ Lihat uraian 'Abd al-Rahmân ibn Khaldûn, Muqaddimah Ibn Khaldûn, editor Suhail Zakkar, (Beirut: Dâr al-Fikr, 2001), vol.1, 744-745.

${ }^{9}$ Nûr al-Dîn 'Itr, "I‘jâzz al-Nubuwwah al-'Ilmî”, dalam Abû Bakr Ahmad ibn 'Alî ibn Tsâbit al-Khathîb al-Baghdâdî,

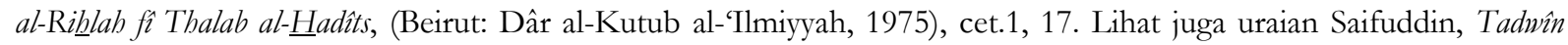
Hadis:Kontribusinya dalam Perkembangan Historiografi Islam, (Banjarmasin: Antasari Press, 2008), cet.1, 247-248.

${ }^{10}$ Lihat 'Abd al-Rahmân ibn Ibrâhîm al-Khumaysî, Mu'jam 'Ulûm al-Hadîts al-Nabawî, (Jeddah: Dâr Ibn Hazm, t.th.), 106.

${ }^{11}$ Muhamammad Dhiyâ' al-Raḩmân al-A'zhamî, Mu'jam Mushthalahât al-Hadîts wa Lathầif al-Asânîd, (Riyâdh: Maktabah Adhwâ' al-Salaf, 1999), 153.

${ }^{12}$ al-Khathîb al-Baghdâdî, al-Jâmi' li Akhlâq al-Râwî wa Âdâb al-Sâmi', editor Muhammad 'Ajjâj al-Khathîb, (Baghdad: Mu'assasah al-Risâlah, t.th.), vol.2, 333 .
} 
yang menjadi rujukan umat Islam hingga sekarang. Dalam hal ini, 'Ajjâj al-Khathîb memberikan gambaran historis perihal perjalanan mencari hadis. Menurutnya, perjalanan (riblab) yang dilakukan pada periode Nabi SAW. lebih bersifat umum, yakni untuk mengetahui ajaran-ajaran agama Islam yang baru. Sementara periode sahabat, tabi'in, dan atbâ' al-tabi'în mencapai tingkat kesempurnaan dengan banyaknya perjalanan ilmiah yang dilakukan oleh para ulama untuk mencari hadis secara khusus. Seringkali tabi'in menempuh jarak yang panjang untuk mendengarkan hadis, mengokohkan dan menguatkannya, atau juga untuk menjumpai sahabat dan tinggal bersama mereka dalam rangka mendapatkan hadis dari sahabat itu, karena sahabat pada periode tabi'in terpencar di berbagai negeri dan mereka membawa serta hadis yang telah dihafalnya. Maka dari itu, bagi orang yang ingin mengumpulkan hadis Nabi SAW. harus berpindah dari satu negeri ke negeri lainnya, menjumpai para sahabat yang pernah mendengarkan hadis dari Nabi SAW., berkonsultasi dengan mereka, serta mengambil hukum-hukum dari mereka.

Untuk selanjutnya, atbâ' al-tabi'în mengadakan perjalanan menemui tabi'in, tinggal bersamanya, dan kemudian mengambil hadis dari mereka. Hingga akhirnya proses penghimpunan hadis menjadi lengkap dalam bentuk buku-buku rujukan yang besar. Seiring dengan itu, perjalanan para ulama masih terus berlanjut dalam rangka mudzâkarah (mendiskusikan) dan 'ardh (membacakan hadis) di hadapan guru-guru hadis yang terkenal. ${ }^{13}$

Dari uraian ini, dapat diketahui bahwa riblah ilmiyyah yang ditradisikan oleh salaf al-shâlih ternyata membawa pengaruh yang sangat besar dalam perkembangan keilmuan Islam, khususnya dalam kajian hadis. Dalam komentarnya, Abû Zahw menyatakan bahwa perjalanan antar ulama dan para guru hadis ini merupakan metode yang sangat baik dalam meningkatkan intelektualitas, menyempurnakan ilmu, dan memelihara hadis nabi. Inilah tradisi ulama yang telah diwariskan sejak zaman Nabi SAW. sampai umat Islam dihinggapi kemalasan, kemandekan, dan meninggalkan hal yang bermanfaat ini dari para pendahulunya. ${ }^{14}$

\section{Sketsa Rihlah 'Ilmiyyah; Penelusuran Periodik}

Seperti yang disinggung sebelumnya, bahwa perjalanan menuntut ilmu ini secara estapet dilakukan sejak masa Nabi Muhammad SAW., sahabat, tâbi'în, atbâ' al-tâbi'în hingga terkodifikasinya kitab-kitab hadis yang sampai ke tangan umat Islam sekarang. Dalam karya alKhathîb al-Baghdâdî yang berjudul al-Riblah fî Thalab al-Hadîts, dikemukakan secara detil berbagai riwayat yang menceritakan tentang perjalanan ilmiah ini. Karya ini menjadi satu-satunya referensi klasik yang menyoroti secara khusus perjalanan menuntut ilmu orang-orang terdahulu dengan gaya penuturan seorang ahli hadis yang selalu menggunakan sanad. Gaya mubaddits seperti ini juga dapat ditemukan dalam karya al-Khathîb al-Baghdâdî lainnya dalam bidang ilmu hadis, yaitu al-Kifâyah fî Tlm al-Riwâyah dan al-Jâmi' li Akhlâq al-Râwî wa Âdâb al-Sâmi'.

Catatan tentang riblah 'ilmiyyah ini dimulai dengan menyebutkan landasan normatif tentang urgensi dan keutamaan melakukan perjalanan ilmiah yang bersumber dari hadis-hadis nabi dan

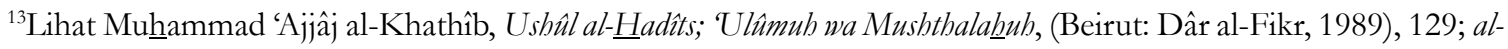
Sunnah Qablal-Tadwîn, (Beirut: Dâr al-Fikr, 1980), cet. 3, 176; Saifuddin, Tadwîn Hadis, 247-248.

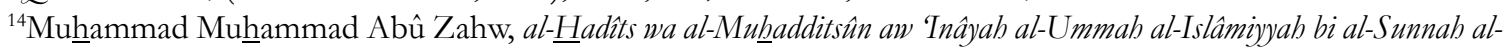
Nabawiyyah, (Mesir: Dâr al-Fikr al-'Arabî, t.th.), 109. 
atsar sahabat. Selanjutnya al-Baghdâdî membagi uraian perjalanan ini dalam lima kategori; pertama, menyebutkan riwayat perjalanan Nabi Musa as. beserta muridnya dalam menuntut ilmu; kedua, menyebutkan riwayat perjalanan para sahabat ra. yang mencari satu hadis; ketiga, menyebutkan riwayat perjalanan para tabi'in dan generasi sesudahnya; keempat, menyebutkan perjalanan menuju guru hadis untuk mencari sanad tertinggi dan wafat sebelum penuntut hadis mencapai maksudnya. ${ }^{15}$

Pada bagian akhir kitab, ditambahkan pula oleh mubaqqiq kitab Rỉlab al-Baghdâdî ini, yaitu Nûr al-Dîn 'Itr, sejumlah riwayat yang melengkapi lima kategorisasi sebelumnya yang tidak diriwayatkan oleh al-Khathîb al-Baghdâdî, atau yang disebut sebagai Istidrâk al-Ziyâdât 'alâ Kitâb al-Rihlah. ${ }^{16}$ Berikut akan diikhtisarkan secara periodik perjalanan menuntut ilmu tersebut, ditambah dengan informasi dari sejumlah referensi lainnya yang relevan.

\section{a. Rihlah Nabi Musa as. beserta Muridnya}

Pada fragmen ini diceritakan tentang perjalanan Nabi Musa as. bersama muridnya untuk belajar kepada Khidhr, karena ketika itu Nabi Musa as. diwahyukan oleh Allah SWT. bahwa ada lagi orang yang lebih alim dari dia yang berada di pertemuan dua lautan. Hal inilah yang mendorong beliau bersama muridnya untuk menuntut ilmu kepada hamba saleh tersebut. Cerita ini diabadikan dalam Q.S. al-Kahf/18:60-82. Dalam beberapa riwayat yang dikutip al-Baghdâdî, disebutkan bahwa hamba Allah tersebut bernama Khidhr, sedangkan murid Nabi Musa as. itu bernama Yûsya' ibn Nûn. ${ }^{17}$

Dalam kisah tersebut, disebutkan bahwa ternyata Nabi Musa as. tidak dapat bersabar terhadap semua yang dilakukan Khidhr dalam perjalanan keduanya, padahal semua yang diperbuatnya memiliki rahasia yang tidak pernah diketahui Nabi Musa as. dan itulah yang akhirnya membuat beliau sadar bahwa ilmu beliau tidak sebanding dengan ilmu Khidhr, padahal sebelumnya Nabi Musa as. mengaku di hadapan orang-orang bahwa dialah orang yang paling alim, maka Allah SWT. pun mengingatkannya bahwa ada yang lebih alim darinya. Riwayatriwayat tersebut memberikan informasi yang cukup detil tentang kisah perjalanan ilmiah Nabi Musa as. yang terdapat dalam al-Qur'an sebelumnya.

\section{b. Rihlah Para Sahabat dalam Mencari Hadis}

Seperti yang diungkapkan oleh 'Ajjâj al-Khathîb sebelumnya, bahwa pada fase Nabi Muhammad SAW. masih hidup, perjalanan ilmiah ini dilakukan oleh orang-orang dalam rangka mendapatkan ajaran-ajaran agama yang baru. Saat itu, ketika mereka mendengar kabar munculnya rasul baru [dari suku Quraisy], mereka pun melakukan perjalanan untuk menemui Rasulullah SAW. untuk mendengarkan ayat-ayat al-Qur'an, mempelajari ajaran-ajaran Islam, kemudian mereka pun kembali kepada kaumnya setelah masuk Islam, sebagaimana yang dilakukan oleh Dhammâm ibn Tsa'labah. ${ }^{18}$ Dalam hal ini, Rasulullah SAW. senantiasa memotivasi

\footnotetext{
${ }^{15}$ Selanjutnya lihat Nûr al-Dîn 'Itr, "I'jâz al-Nubuwwah al-'Ilmî” dalam al-Khathîb al-Baghdâdî, al-Rịhlah fî Thalab al-

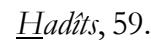

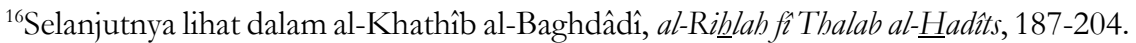

${ }^{17}$ Selanjutnya lihat keterangan al-Khathîb al-Baghdâdî, al-Rihlah fî̀ Thalab al- $\underline{H}$ adîts, 97-107.

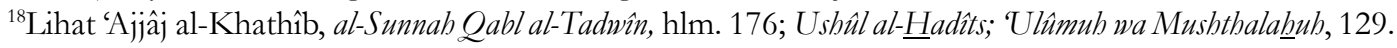


para sahabatnya untuk mencari ilmu dan melakukan perjalanan dalam mendapatkannya. Maka sebagian sahabat yang tempat tinggalnya jauh, melakukan perjalanan ke Madinah untuk bertanya langsung kepadanya seputar persoalan agama. ${ }^{19}$

Pasca wafatnya Nabi SAW., tradisi riblah ini terus dilanjutkan oleh para sahabat ra. yang saling melakukan perjalanan antara yang satu dengan yang lainnya dalam mencari hadis. Pada fragmen ini, al-Khathîb al-Baghdâdî mencatat sejumlah nama sahabat yang aktif melakukan perjalanan mencari hadis, seperti Jâbir ibn 'Abd Allâh (w. 78 H.), ketika sampai kepadanya sebuah hadis yang konon berasal dari salah seorang sahabat Nabi saw., maka ia membeli unta, lalu mengadakan perjalanan dengan unta itu selama satu bulan hingga sampai di negeri Syria, dan ternyata sahabat yang dimaksud adalah 'Abd Allâh ibn Unays, maka Jâbir menanyakan langsung hadis itu kepadanya. ${ }^{20}$

Sahabat lainnya, Abû Ayyûb al-Anshârî (w. 52 H.) pernah mengadakan perjalanan dari Madinah ke Mesir hanya untuk memastikan kebenaran sebuah hadis dari 'Uqbah ibn 'Âmir. Hal ini dilakukannya karena khawatir jikalau ada kesalahan dalam hadis tersebut yang sampai kepadanya, sedangkan tidak ada satupun sahabat lain yang menerima hadis itu selain dia [Abû Ayyûb] dan 'Uqbah saja. ${ }^{21}$ Sementara Abû al-Dardâ' (w. 32 H.), salah seorang sahabat senior, menyatakan; "seandainya aku mendapati kesulitan memahami ayat al-Qur'an, tetapi tidak ada yang dapat membantu memecahkannya kecuali seseorang yang tinggal di Birk al-Ghimâd, ${ }^{22}$ tentu aku akan mengadakan perjalanan ke sana." 23

\section{c. Rihlah Para Tabi'in \& Generasi Sesudahnya}

Memasuki periode tabi'in, ketika hadis mulai tersebar ke berbagai daerah, seiring dengan semakin luasnya wilayah kekuasaan Islam, perjalanan mencari hadis tambah gencar dilakukan oleh ulama. Dalam hal ini, al-Khathîb al-Baghdâdî mencatat sejumlah besar nama tabi’in, semisal Sa'îd ibn al-Musayyab (w. 94 H.), yang pernah mengadakan perjalanan siang dan malam selama beberapa hari hanya untuk mendapatkan sebuah hadis. ${ }^{24}$

Beberapa tabi'in lainnya, seperti Abû Qilâbah (w. 104 H.) mengaku pernah tinggal selama tiga hari di Madinah untuk bertemu dengan seseorang yang memiliki hadis agar dapat meriwayatkan hadis darinya. ${ }^{25} \mathrm{Al}-\underline{\mathrm{H}}$ asan al-Bashrî (w. $110 \mathrm{H}$.) juga pernah mengadakan perjalanan dari Bashrah ke Kufah menemui Ka'ab ibn 'Ujrah untuk menanyakan suatu masalah. ${ }^{26}$ Demikian

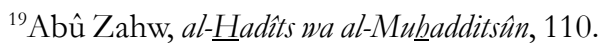

${ }^{20}$ al-Khathîb al-Baghdâdî, al-Kifâyah fì Tlm al-Riwâyah, (Beirut: Dâr al-Kutub al-'Ilmiyah, 1988), 402; al-Rihlah fî Thalab

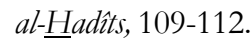

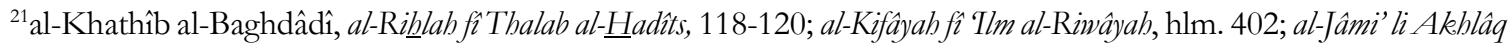
al-Râmîwa Âdâb al-Sâmi',337.

${ }^{22}$ Birk al-Ghimâd sejauh ini menunjuk pada dua tempat; pertama, sebuah tempat yang letaknya jauh di belakang kota Makkah; kedua,suatu daerah yang berada di negeri Yaman. Menurut Ibn al-Dumaynah, yang dimaksud Birk al-Ghimâd dalam pernyataan Abû al-Dardâ' adalah daerah yang letaknya paling jauh di Yaman. Lihat Abû 'Abd Allâh Yâqût ibn 'Abd Allâh al- Hamawî al-Rûmî al-Baghdâdî, Mu'jam al-Buldân, (Beirut: Dâr Shâdir, t.th.), vol.1, 399-400.

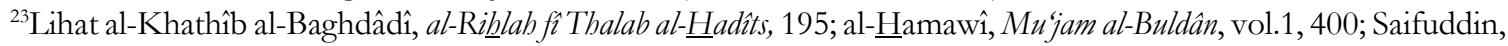
Tadwin Hadis, 250.

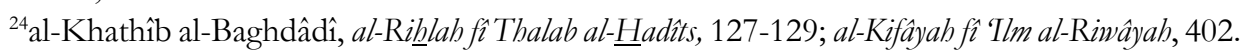

${ }^{25}$ al-Khathîb al-Baghdâdî, al-Rīhlah fì Thalab al- $\underline{\underline{H}}$ adîts, 144-145.

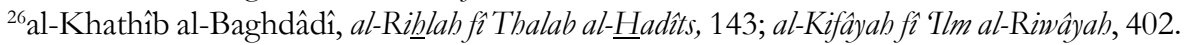




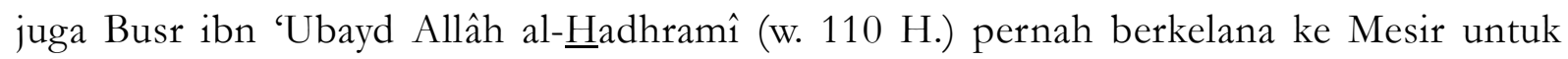
mendengarkan sebuah hadis. ${ }^{27}$ Ibn Syihâb al-Zuhrî (w. 124 H.) menyatakan pernah pula melakukan pengembaraan ke Syria menjumpai 'Athâ' ibn Yazîd, Ibn Muhayrîz, dan Ibn Haywah, lalu ke Mesir, Irak, dan negeri-negeri Islam lainnya untuk mencari hadis. ${ }^{28}$

Lebih lanjut, perjalanan mencari hadis menjadi fenomena yang sangat umum pada periode atbâ' al-tâbi în dan periode-periode setelahnya. Dalam hal ini, Azami dalam bukunya Studies in

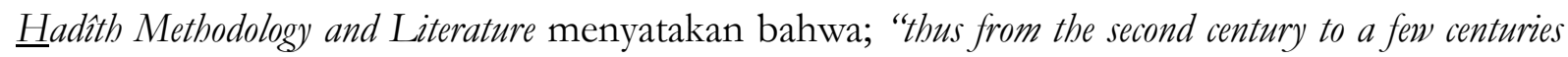
later general requirement of a student of hadîth was to make extensive journeys for learning hadith” "[sejak abad kedua hingga beberapa abad sesudahnya, tuntutan umum bagi seorang pengkaji hadis adalah melakukan perjalanan yang ekstensif mempelajari hadis]. ${ }^{29}$ Pada abad-abad ini, banyak sekali ulama hadis dari generasi atbâ' al-tâbi'în, dan atbâ' atbâ' al-tâbi'în, dan seterusnya yang melakukan perjalanan dari negeri asalnya menuju berbagai negeri Islam lainnya untuk mendapatkan hadis-hadis nabi.

Dalam fragmen ini, al-Khathîb al-Baghdâdî mencatat sejumlah besar nama, semisal Syu'bah ibn al- $\underline{\text { Hajjâj }}$ (w. 160 H.), untuk mengecek keberadaan hadis, mengadakan perjalanan ke Makkah menjumpai 'Abd Allâh ibn 'Athâ', dan ternyata Ibn 'Athâ' mendapatkan hadis itu dari Sa'd ibn Ibrâhîm. Maka Syu'bah pun mengadakan perjalanan ke Madinah untuk menemui Sa'd, dan ternyata hadis itu diterima Sa'd dari Ziyâd ibn Mikhraq. Kemudian Syu'bah melanjutkan perjalanan ke Bashrah untuk menemui Ziyâd dan ternyata Ziyâd menerima hadis itu dari Syahr

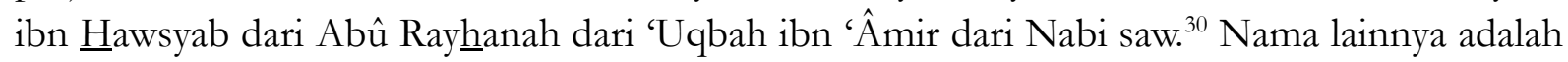
seperti Sufyân al-Tsawrî (w. 161 H.) telah melakukan perjalanan dari Kufah ke Bashrah, kemudian ke Yaman, untuk mendapatkan suatu hadis. ${ }^{31}$

Pada periode atbâ' atbâ' al-tâbi'în ini, muncul para ulama hadis kenamaan, dengan karyakarya hadis monumental mereka yang dikenal dengan istilah kutub al-sittah, yaitu al-Bukhârî (w. 256 H.), Muslim (w. 261 H.), Abû Dâwûd (w. 275 H.), al-Tirmidzî (w. 279 H.), al-Nasâ'î (w. 303 H.), dan Ibnu Mâjah (w. 273 H.). Dalam hal ini, Syawqî Abû Khalîl dalam karyanya Athlas al-

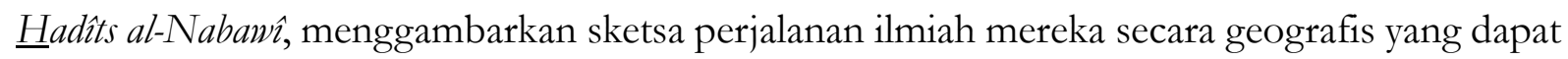
diikhtisarkan sebagai berikut; ${ }^{32}$

${ }^{27}$ al-Khathîb al-Baghdâdî, al-Rihlah fî Thalab al- $\underline{H}$ adîts, 147-148.

${ }^{28 ‘ A j j a ̂ j ~ a l-K h a t h i ̂ b, ~ U s h u ̂ l ~ a l-\underline{H} a d i ̂ t s, ~ h l m . ~ 133 ; ~ a l-S u n n a h ~ Q a b l ~ a l-T a d w i ̂ n, ~ 178-181 . ~}$

${ }^{29}$ Selanjutnya lihat Muhammad Mustafa Azami, Studies in $\underline{\text { H}}$ adith Methodology and Literature, (Indianapolis: American Trust Publications, 1977), 50.

${ }^{30}$ al-Khathîb al-Baghdâdî, al-Rihlah fî Thalab al- $\underline{H}$ adîts, 152-153.

${ }^{31}$ ‘jjâj al-Khathîb, al-Sunnah Qabl al-Tadwin, 181.

${ }^{32}$ Lihat Syawqî Abû Khalîl, Athlas al-Hadîts al-Nabawî min al-Kutub al-Shihhhâh al-Sittah, (Damaskus: Dâr al-Fikr, 2005), cet.4, 11-16. 
Sketsa Rihlah 'Ilmiyyah al-Bukhârî

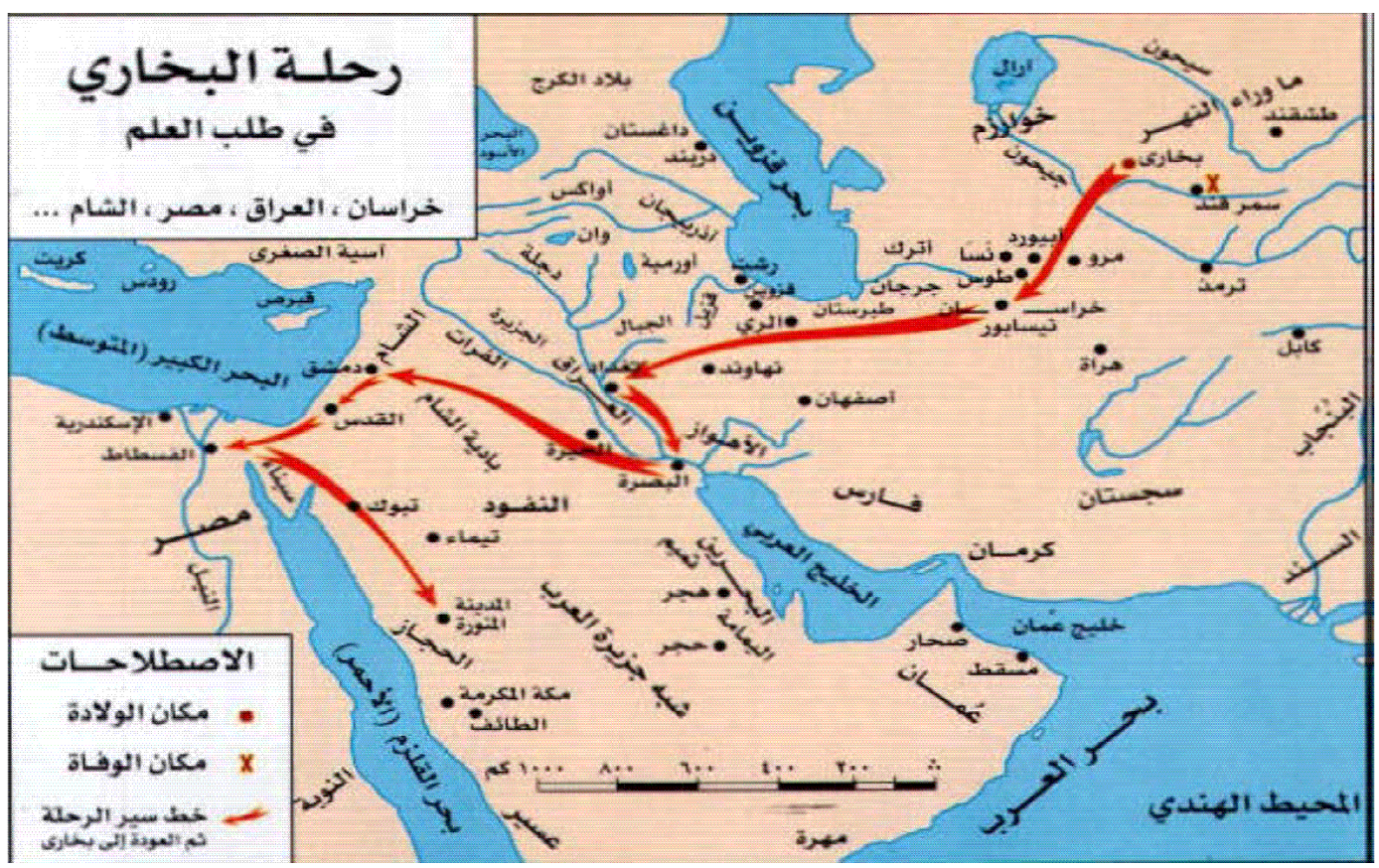

Sketsa Rihlah 'Ilmiyyah Muslim

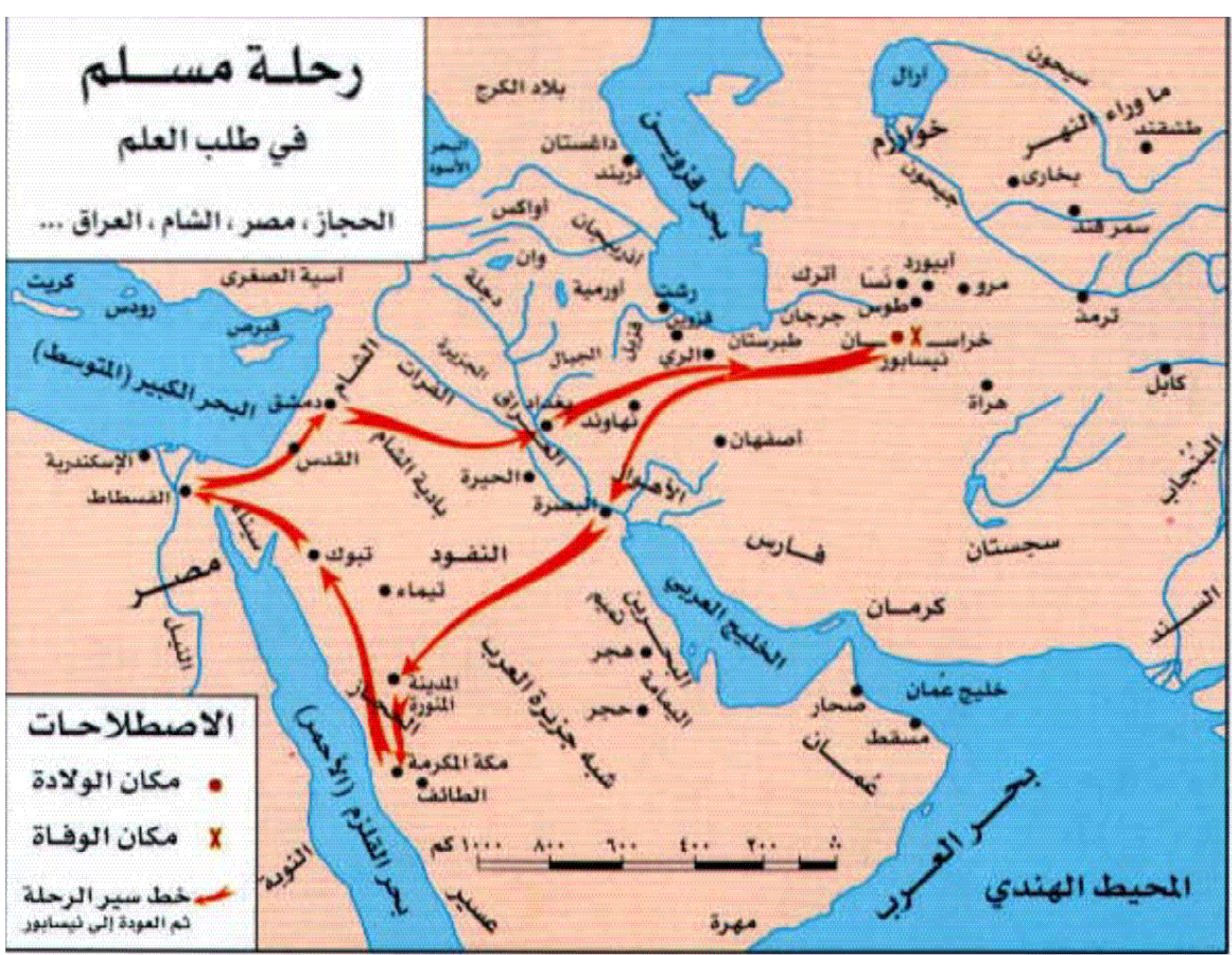


Sketsa Rihlah 'Ilmiyyah Abû Dâwûd

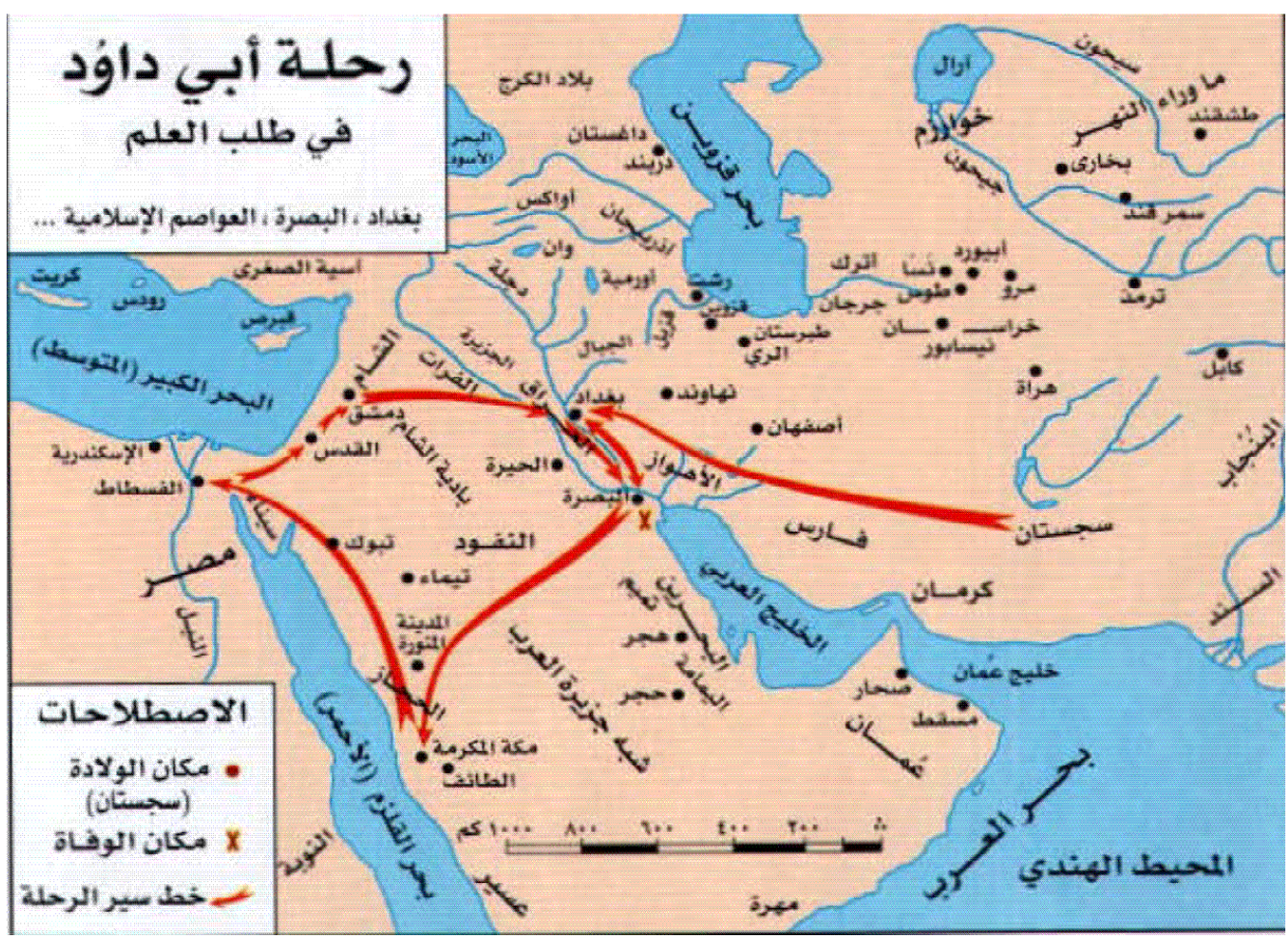

Sketsa Rihlah 'Ilmiyyah al-Tirmidzî

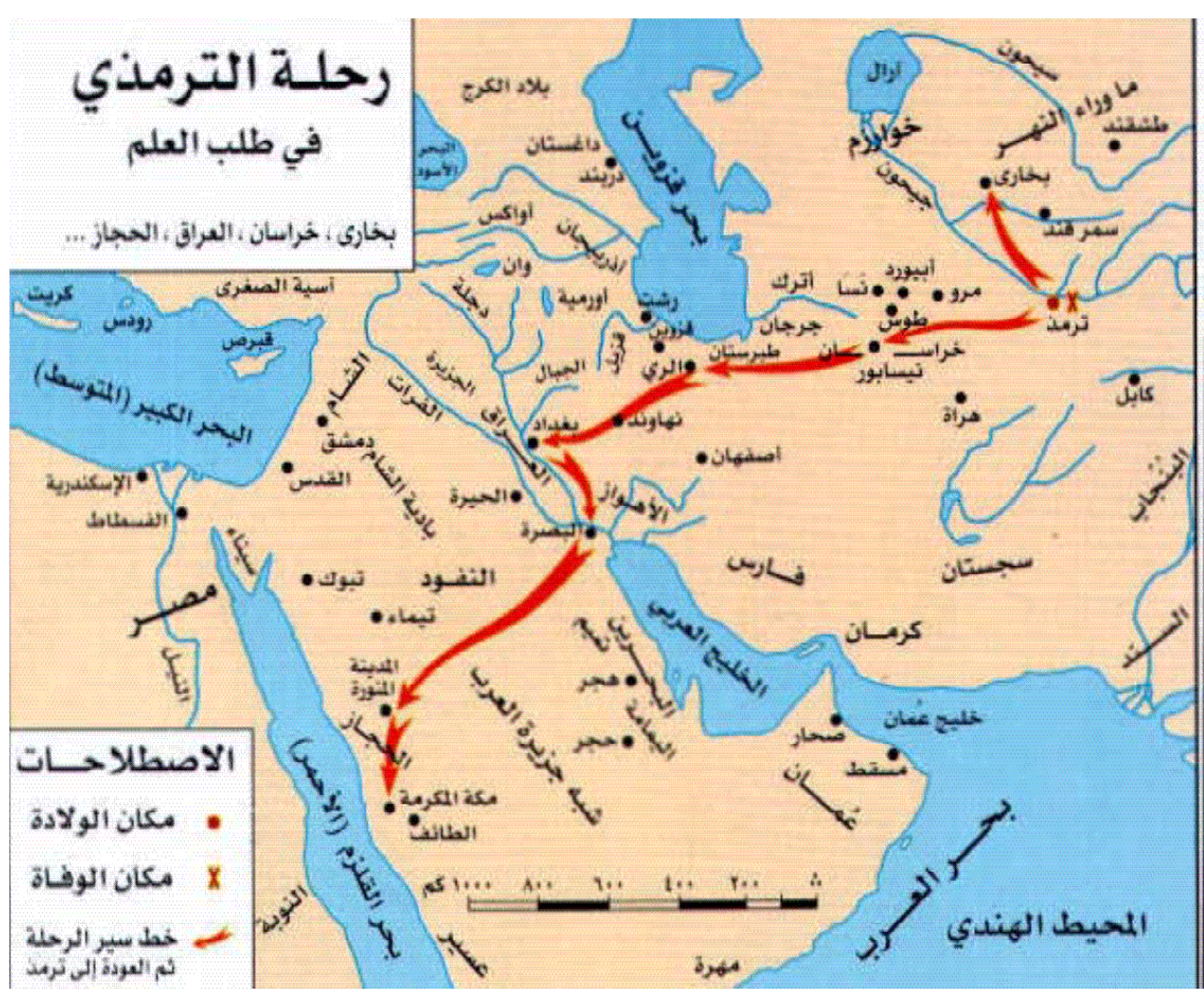


Sketsa Rihlah 'Ilmiyyah al-Nasâ'î

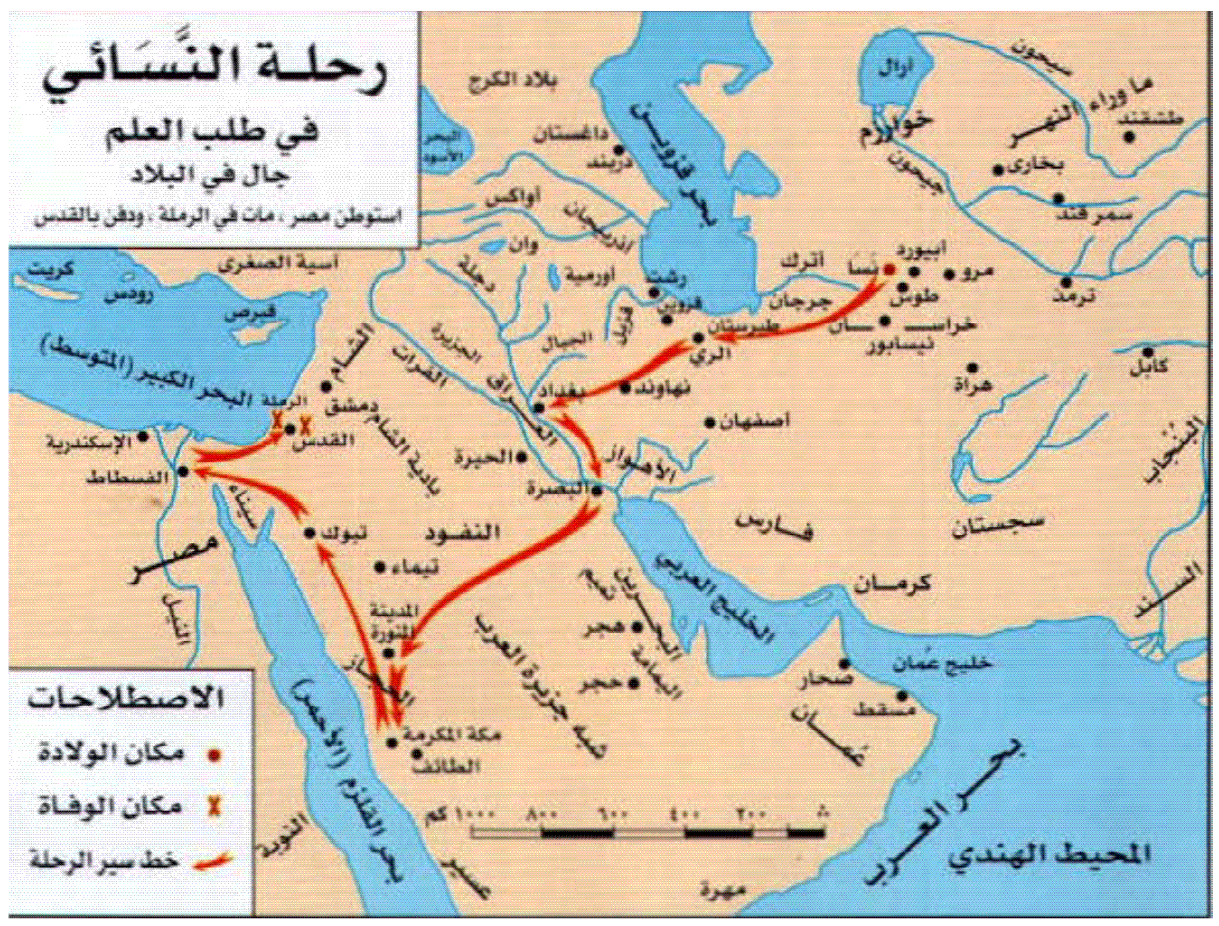

Sketsa Rihlah 'Ilmiyyah Ibnu Mâjah

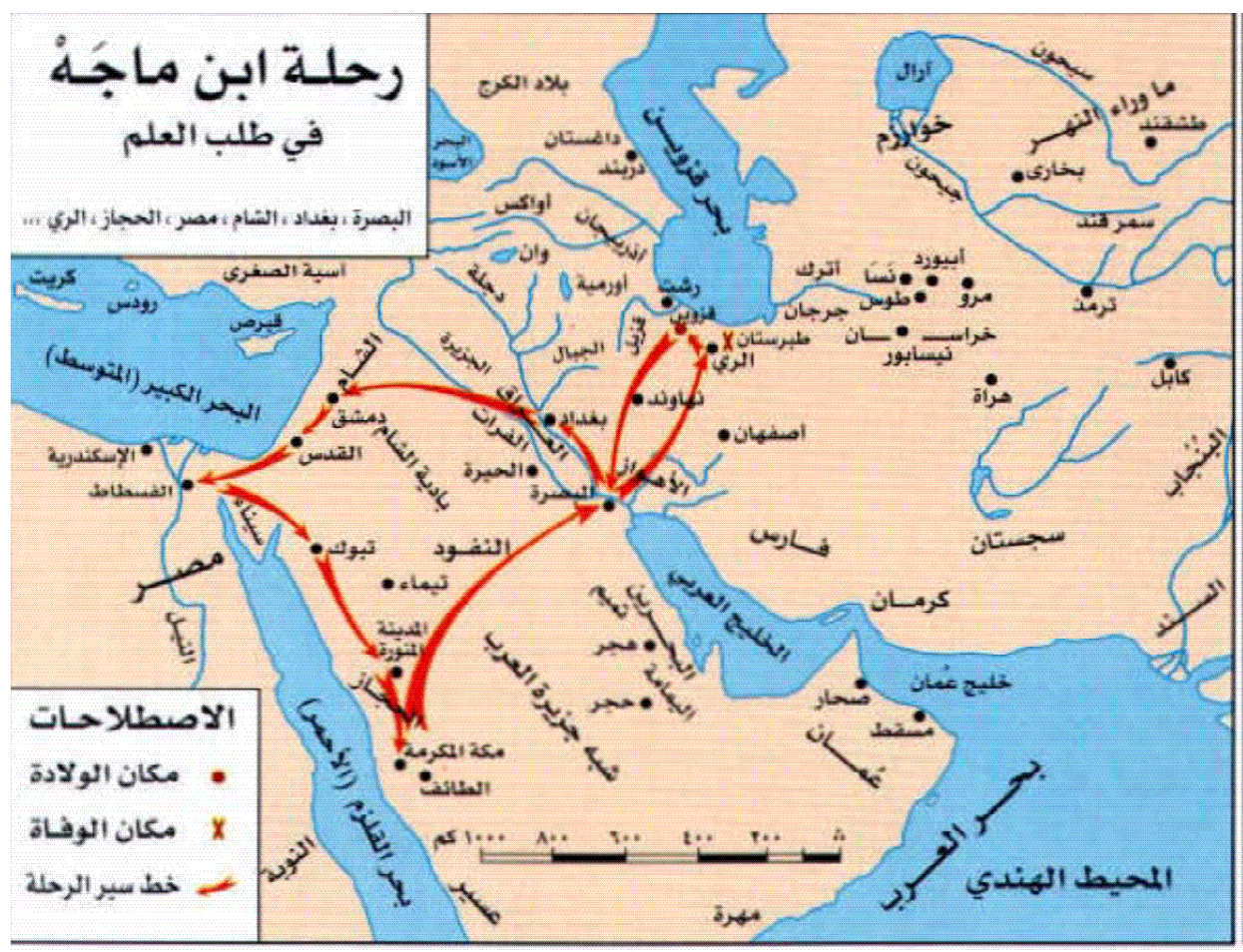




\section{d. Rihlah Mencari Sanad Hadis Tertinggi}

Dalam fragmen ini, al-Khathîb al-Baghdâdî meriwayatkan perjalanan mereka yang belum sempat menemui guru hadis karena wafat sebelum bertemu. Riwayat ini dimulai dari perjalanan sahabat dan tabi'in senior yang ingin mendengar hadis dari Nabi SAW. namun beliau wafat sebelum bertemu. Tercatat beberapa nama tabi'in yang dikutip riwayatnya seperti 'Abd alRahmân ibn 'Usaylah al-Shunâbihî dan Zayd ibn Wahb. ${ }^{33}$

Tabi'in lainnya seperti al-Awzâ'î, menceritakan perjalanannya menuju al-Hasan yang wafat sebelum keduanya bertemu, lalu menuju Ibnu Sîrîn dan sempat bertemu, namun dalam keadaan sakit dan beberapa hari kemudian wafat. Begitu pula dengan 'Abbâs ibn Yazîd yang ketika menuju Kufah bersama ayahnya, hanya sempat bertemu dengan jenazah gurunya, Abû Ishâq al-Hamdânî, juga seperti al-Qâsim ibn Sallâm yang menuju Bashrah untuk berguru dengan Hammâd ibn Zayd, kemudian seperti al-'Tjlî yang ingin bertemu dan berguru dengan Abû Dâwûd al-Thayâlisî, namun tidak sempat bertemu karena sudah wafat. ${ }^{34}$

Dari periodesasi ini, dapat diketahui adanya pergeseran paradigma dalam melakukan riblah ilmiyyah, setidaknya dalam beberapa hal; pertama, bahwa pada masa Rasulullah SAW., riblah ilmiyyah dilakukan untuk mendapatkan ilmu agama, khususnya dalam bidang al-Qur'an dan hadis, serta untuk belajar hukum langsung dari Nabi SAW.; kedua, pada masa sahabat dan tabi'in, riblah ilmiyyah dilakukan untuk mencari keabsahan sanad hadis dari para sahabat yang tsiqah; ketiga, setelah ilmu hadis dibukukan, maka perlawatan ilmiah lebih ditujukan untuk mencari guru ataupun mendengar hadis untuk selanjutnya diperbincangkan dan didiskusikan.

Dari beberapa uraian yang telah dikemukakan tadi, dapat diketahui bahwa generasi salaf al-shâlih memang memiliki semangat keilmuan yang begitu besar sehingga rela melakukan perjalanan yang jauh dan memberatkan hanya untuk mendengarkan hadis-hadis nabi dari sumbernya langsung. Tentunya perjalanan ilmiah untuk mencari hadis diakui mempunyai pengaruh yang besar terhadap penyebaran (nasyr), pengumpulan (jam), pengujian (tambîsh), dan juga pengokohan (tatsabbut) hadis. ${ }^{35}$

Bahkan menurut Saifuddin, perjalanan ilmiah (riblah) yang ditempuh oleh para ulama untuk mencari hadis mempunyai peran yang sangat sentral bagi kegiatan tadwin hadis. Peran itu ternyata tidak hanya terbatas pada proses penghimpunan hadis, tetapi juga pada proses penyeleksian ataupun penyusunan hadis ke dalam karya-karya besar yang banyak dirujuk oleh umat Islam hingga sekarang. ${ }^{36}$ Dampak lain dari perjalanan ilmiah itu, seperti dituturkan Shubhî al-Shâlih adalah berupa penyatuan nash hadis, dan mengubah wataknya dari warna kedaerahan ke warna umum yang universal. Selain itu, perjalanan mencari hadis ini juga berdampak pada penyatuan hukum dan akidah. ${ }^{37}$

\footnotetext{
${ }^{33}$ al-Khathîb al-Baghdâdî, al-Rihlah fi Thalab al- $\underline{H}$ adìts, 166-167.

${ }^{34}$ al-Khathîb al-Baghdâdî, al-Rihlah fì Thalab al- $\underline{H}$ adîts, 168-181.

35‘Ajjâj al-Khathîb, Ushûl al- $\underline{H}$ adîts, 134; Saifuddin, Tadwîn Hadis, 254.

${ }^{36}$ Saifuddin, Tadwin Hadis, 256.

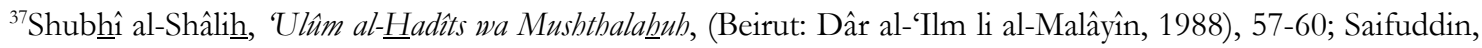
Tadwin Hadis, 254. 


\section{Rihlah 'Ilmiyyah ; Tujuan dan Fungsinya dalam Konteks Intelektual}

Dalam uraiannya, Nûr al-Dîn 'Itr menyatakan bahwa perjalanan ilmiah yang dilakukan oleh para ulama dalam mencari hadis memiliki tujuan dan fungsi penting yang diikhtisarkannya sebagai berikut:

a. Untuk memperoleh hadis. Boleh jadi hal ini merupakan sebab pertama dari perjalanan mencari hadis, khususnya pada periode-periode awal Islam seperti perjalanan para sahabat, tabi'in, dan seterusnya;

b. Untuk mengokohkan hadis. Hal ini dapat digambarkan misalnya ada seorang ahli hadis memiliki hadis-hadis yang diriwayatkan dari orang lain, kemudian dalam perjalanan mencari hadis ia mendengarkan pula sebagian dari hadis-hadis yang telah ada padanya dan sanad hadis itu bertemu dengan sanad-nya sendiri serta ada kesamaan lafal maupun makna dengan matan hadis yang telah diriwayatkannya, atau juga dalam perjalanannya itu, ahli hadis bersangkutan mendengarkan pula hadis-hadis lain yang semakna dengan hadis yang telah dia riwayatkan, sehingga ia menjadi tenang dan hadisnya pun menjadi kuat;

c. Untuk mencari sanad yang tinggi. Ahli hadis dapat saja memperoleh sanad yang tinggi jika dia mendengarkan hadis dari salah seorang perawi dan perawi itu menerimanya dari seorang guru, maka selanjutnya ahli hadis bersangkutan pergi menemui guru itu dan mendengarkan hadis langsung darinya;

d. Untuk meneliti hal-ihwal perawi hadis. Sejumlah kritikus hadis, ketika berusaha melacak keadilan dan kekuatan hafalan yang dimiliki oleh para perawi hadis, juga telah melakukan perjalanan ilmiah ke berbagai tempat dan menjumpai sejumlah perawi hadis;

e. Untuk berdiskusi dengan para ulama dalam hal kritik hadis berikut cacat-cacatnya. Hal ini antara lain dapat dijumpai dalam kasus 'Alî ibn al-Madînî yang mengadakan perjalanan dari Irak menuju kepada Sufyân ibn 'Uyaynah di Makkah mendiskusikan perihal kritik hadis dan cacat-cacatnya. ${ }^{38}$

Sedangkan manfaat riblah yang dikemukakan oleh beberapa sarjana adalah sebagai berikut; Pertama, untuk pengokohan dari sisi ilmiah. Sebuah perjalanan ilmiah mesti dilakukan dalam upaya menuntut ilmu agar dapat memperoleh sejumlah manfaat dan kesempurnaan ketika bertemu langsung dengan beberapa guru serta bergaul dengan banyak orang;

Kedua, untuk penyebaran ilmu yang telah dihasilkan oleh ulama. Bagaimanapun perjalanan ilmiah yang dilakukan oleh seorang ulama ataupun sastrawan menjadi salah satu sebab bagi kemunculan ilmu atau sastra berikut penyebarannya ke berbagai daerah

Ketiga, untuk perluasan budaya masyarakat Islam. Ketika mengadakan pengembaraan ilmiah ke berbagai negeri, para ulama dapat mengadakan kontak dengan orang-orang yang beragam budaya dan tradisi. Dari sini bisa terjadi pertukaran budaya ketika para ulama pengembara berpindah dari satu negeri ke negeri lainnya dan bersamaan dengan itu mereka mengabarkan kepada penduduk setempat mengenai berbagai hal, termasuk tradisi dan budaya masyarakat dari negeri-negeri yang pernah disinggahinya;

\footnotetext{
${ }^{38}$ Selanjutnya lihat Nûr al-Dîn, "I'jầz al-Nubuwwah al-'Ilmî” dalam al-Khathîb al-Baghdâdî, al-Rihlilah fî Thalab al-

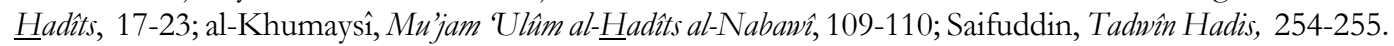

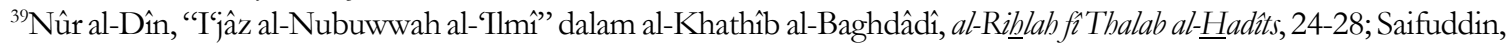
Tadwin Hadis, 255-256.
} 
Keempat, untuk menumbuhkan keutamaan dan kesempurnaan jiwa. Hal ini justru yang dikejar oleh para ulama pengembara ketika melakukan pengembaraan. Para ahli kebajikan tentu saja berkeinginan untuk mengikuti perilaku dan sifat mereka;

Kelima, untuk mendapatkan sahabat-sahabat baru yang tulus. Perjalanan ilmiah ternyata menjadi sarana efektif untuk mendapatkan kawan-kawan baru yang saling kenal, terbuka untuk membicarakan keutamaan-keutamaan dan kebaikan-kebaikan mereka dalam majelis. Hal itu bisa mengantarkan kepada sikap saling kenal dan cinta antar suku atau bangsa. Karenanya tidak heran jika antar sesama umat Islam terjalin rasa cinta dan kerjasama yang tinggi, sehingga seluruh negeri Islam terbuka bagi setiap orang yang beragama Islam. ${ }^{39}$

Dari uraian ini, jelaslah bahwa riblah ilmiyyah ternyata memiliki kontribusi yang sangat besar dalam pengembangan ilmu dan dakwah agama. Hal ini dikarenakan perpindahan para ulama dari satu tempat ke tempat yang lain secara otomatis berarti pula penyebaran ilmu pengetahuan.

\section{Penutup}

Sebagai catatan akhir dalam bagian ini, perlu dikemukakan juga bahwa masyarakat muslim yang melakukan riblab ilmiyyah pada periode klasik, tidak dibatasi adanya sistem kewarganegaraan (citizenship), sehingga mereka bebas melakukan riblah dengan menjelajahi berbagai negara tanpa terikat dengan kewajiban mengurus paspor atau visa. Namun demikian, tujuan riblah sebenarnya cukup beragam sesuai dengan perkembangan masyarakat sekarang.

Adanya perkembangan teknologi dan informasi sekarang yang sudah semakin maju, serta dapat diakses dengan mudah secara online kapan pun dan dimana pun, bukan berarti riblah ilmiyyah pada saat ini menjadi kurang relevan lagi. Sebab bagaimana pun, pertemuan langsung dengan para guru tetap diperlukan dalam rangka menjaga etika ilmiah dan objektivitas keilmuan yang pada gilirannya akan menghasilkan nilai kebaikan yang berkesinambungan, atau dalam bahasa agama disebut sebagai 'berkah' ilmu. Inilah yang menjadi movitasi para ulama klasik untuk tetap melakukan tradisi perlawatan mencari ilmu ini ke wilayah-wilayah lain yang jauh, meskipun harus melalui kesulitan dan hambatan.

\section{DAFTAR PUSTAKA}

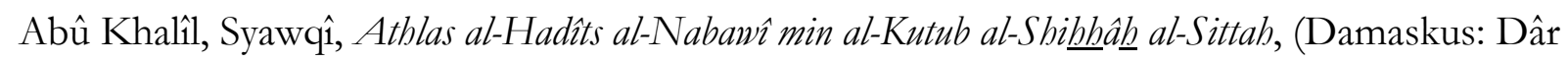
al-Fikr, 2005).

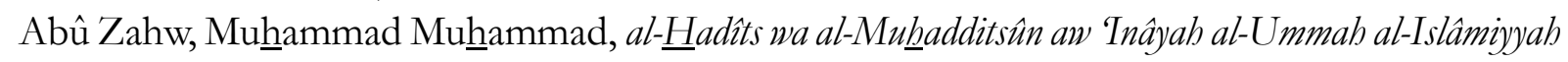
bi al-Sunnah al-Nabawiyyah, (Mesir: Dâr al-Fikr al-'Arabî, t.th.).

Al-A'zhamî, Muhammad Dhiyâ' al-Rahnmân, Mu'jam Mushthalahâat al-Hadîts wa Lathầif al-Asânîd, (Riyâdh: Maktabah Adhwâ' al-Salaf, 1999).

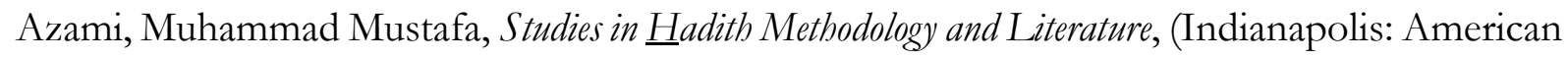
Trust Publications, 1977).

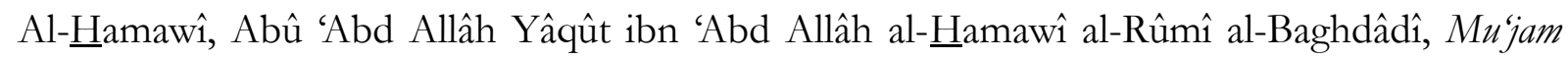
al-Buldân, (Beirut: Dâr Shâdir, t.th.).

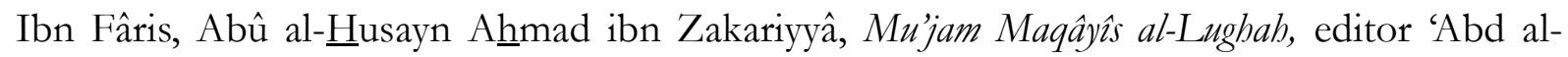
Salâm Muhammad Hârûn, (Beirut: Dâr al-Fikr, 1979). 
Ibn Katsîr, Abû al-Fidâ' al-Hâfizh al-Dimasyqî, Tafsîr al-Qur'ân al-'Az̧him, (Beirut: Dâr al-Fikr, 2009).

Ibn Khaldûn, 'Abd al-Rahmân, Muqaddimah Ibn Khaldûn, editor Suhail Zakkar, (Beirut: Dâr alFikr, 2001).

Ibn Manzhûr, Muhammad ibn Mukarram ibn 'Alî ibn Muhammad ibn Abû al-Qâsim ibn Habqah, Lisân al-'Arab, (Kairo: Dâr al-Ma'ârif, t.th.)

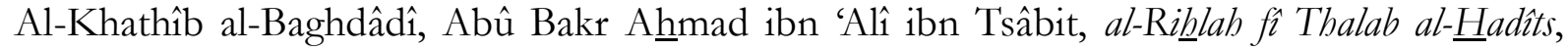
(Beirut: Dâr al-Kutub al-'Ilmiyyah, 1975).

, al-Jâmi' li Akblâq al-Râwî wa Âdâb al-Sâmi', editor Muhammad 'Ajjâj al-Khathîb, (Baghdad: Mu'assasah al-Risâlah, t.th.). , al-Kifâyah fî Tlm al-Riwâyah, (Beirut: Dâr al-Kutub al-'Ilmiyah, 1988).

Al-Khathîb, Muhammad 'Ajjâj, al-Sunnah Qabl al-Tadwîn, (Beirut: Dâr al-Fikr, 1980).

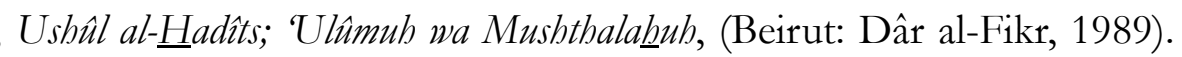

Al-Khumaysî, 'Abd al-Rahmân ibn Ibrâhîm, Mu'jam 'Ulûm al-Hadîts al-Nabawñ, (Jeddah: Dâr Ibn $\underline{H}$ azm, t.th.).

Saifuddin, Tadwîn Hadis: Kontribusinya dalam Perkembangan Historiografi Islam, (Banjarmasin: Antasari Press, 2008).

Al-Shâbûnî, Muhammad 'Alî, Shafwah al-Tafâsir, (Beirut: Dâr al-Fikr, 2001), vol.3, hlm. 580.

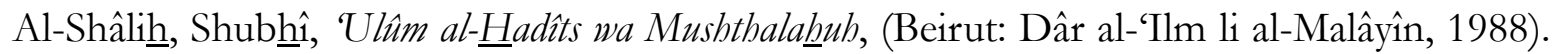

Al-Tirmidzî, Abû 'Îsâ Muhammad ibn 'Îsâ ibn Sawrah, al-Jâmi al-Shabîh w wa huwa Sunan al-

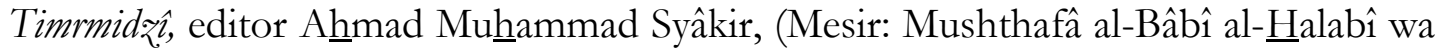
Awlâduh, t.th.). 